\title{
PENINGKATAN KEAKTIFAN DAN HASIL BELAJAR SISWA DENGAN PENERAPAN METODE TUTOR SEBAYA
}

\author{
Gaspar Naju Kaduwu Wali ${ }^{1}$, Wignyo Winarko ${ }^{2}$, Tatik Retno Murniasih ${ }^{3}$ \\ Program Studi Pendidikan Matematika Universitas Kanjuruhan Malang ${ }^{1,2,3}$ \\ gasparwali0511@gmail.com¹,wignyowinarko@gmail.com², tretnom@unikama.ac.id ${ }^{3}$
}

\begin{abstract}
Abstrak. Permasalahan utama pada penelitian ini adalah rendahnya hasil belajar siswa kelas VIII G SMP Negeri 1 Wagir. Salah satu faktor yang menyebabkan rendahnya hasil belajar tersebut adalah siswa kurang aktif dalam pembelajaran matematika di kelas. Dengan demikian, penelitian bertujuan untuk meningkatkan keaktifan dan hasil belajar siswa kelas VIII SMP Negeri 1 Wagir dengan menerapkan metode tutor sebaya. Penelitian ini terdiri dari empat tahap yaitu perencanaan (plan), pelaksanaan (action), pengumpulan data (observe), dan refleksi (reflection). Prosedur pengumpulan data yang digunakan dalam penelitian ini adalah lembar observasi, lembar keaktifan, tes dan wawancara. Hasil penelitian ini menunjukkan penerapan metode tutor sebaya dapat meningkatkan keaktifan dan hasil belajar siswa kelas VIII G SMP Negeri 1 Wagir. Peningkatan keaktifan dan hasil belajar siswa dilihat dari persentase yang diperoleh pada siklus I dan Siklus II dengan rincian sebagai berikut: (1) persentase keaktifan belajar siswa pada siklus I sebesar 71,67\% sedangkan pada siklus II mengalami peningkatan menjadi 83,33\%, dan (2) hasil belajar siswa pada siklus I sebesar $60,71 \%$ sedangkan pada siklus II mengalami peningkatan menjadi $78,57 \%$. Saran bagi peneliti lain dapat menggunakan metode tutor sebaya untuk diterapkan dalam pembelajaran matematika dengan menggunakan materi yang berbeda.

Kata Kunci: metode tutor sebaya, keaktifan dan hasil belajar
\end{abstract}

\section{PENDAHULUAN}

Matematika adalah mata pelajaran yang diberikan kepada semua jenjang pendidikan dimulai dari sekolah dasar untuk membekali siswa dengan kemampuan berfikir logis, analitis, sistematis, kritis, dan kreatif, serta kemampuan bekerja sama (Sholihah, 2015:3). Mata pelajaran matematika sangat bermanfaat bagi siswa sebagai ilmu dasar untuk penerapan di bidang lain. Salah satu contohnya pada saat kita berbelanja atau melakukan kegiatan jual beli barang atau pada saat mengikuti pelajaran fisika pasti menemukan penggunaan konsep matematika. Begitu pentingnya peranan matematika dalam kehidupan tidak didukung dengan fakta yang terjadi di lapangan dimana hasil belajar matematika siswa sekolah menengah masih tergolong rendah.

Berdasarkan hasil observasi yang dilakukan peneliti dalam proses pembelajaran di SMP Negeri 1 Wagir khusus kelas VIII G, ditemukan bahwa hasil belajar yang diperoleh siswa masih rendah. Hal ini didukung dengan hasil belajar yang diperoleh siswa pada saat melaksanakan ulangan harian 4 dengan pokok bahasan persamaan garis lurus. siswa dinyatakan tidak tuntas dalam belajar secara klasikal karena persentase ketuntasan siswa kurang dari $76 \%$ (Kriteria Ketuntasan Minimum). Rendahnya hasil belajar yang diperoleh siswa dikarenakan kurang memperhatikan penjelasan guru dan kurang aktif dalam proses pembelajaran di kelas. Sementara itu, Mulyasa (dalam Wibowo, 2016:130) mengatakan pembelajaran dikatakan berhasil dan berkualitas apabila seluruhnya atau setidaktidaknya sebagian besar siswa terlibat secara aktif, baik fisik, mental maupun sosial dalam proses pembelajaran.

Dalam upaya meningkatkan keaktifan siswa, guru dapat berperan dengan merekayasa sistem pembelajaran secara sistematis, sehingga dapat merangsang keaktifan peserta didik dalam proses pembelajaran. Kegiatan-kegiatan guru yang dapat mempengaruhi keaktifan siswa menurut Usman (dalam Wibowo, 2016:131) adalah: (1) memberikan motivasi atau menarik perhatian siswa, sehingga mereka berperan aktif dalam kegiatan pembelajaran; (2) menjelaskan tujuan instruksional (kemampuan dasar kepada siswa); (3) mengingatkan kompetensi belajar kepada siswa; (4) memberikan stimulus (masalah, topik, dan konsep yang akan dipelajari); (5) 
memberikan petunjuk kepada siswa cara mempelajari; 6) memunculkan aktifitas, partisipasi siswa dalam kegiatan pembelajaran, (7) memberikan umpan balik (feedback); (8) melakukan tagihan-tagihan kepada siswa berupa tes sehingga kemampuan siswa selalu terpantau dan terukur; dan (9) menyimpulkan setiap materi yang disampaikan diakhir pembelajaran.

Sardiman (dalam Zayyin, 2017:13) mengemukakan bahwa keaktifan adalah kegiatan yang bersifat fisik maupun mental, yaitu berbuat dan berfikir sebagai suatu rangkaian yang tidak dapat dipisahkan Belajar yang berhasil harus melalui berbagai macam aktivitas, baik aktivitas fisik maupun psikis. Sementara itu, Aunurrahman (dalam Mulyani, 2017:411) mengemukakan bahwa keaktifan siswa dalam belajar merupakan persoalan penting dan mendasar yang harus dipahami, dan dikembangkan setiap guru dalam proses pembelajaran. Sehingga keaktifan siswa perlu digali dari potensi-potensinya melalui aktivitasnya untuk mencapai tujuan pembelajaran.

Mengatasi pemasalahan diatas, peneliti memutuskan untuk menggunakan strategi/metode dalam melaksanakan pembelajaran selanjutnya. Metode pembelajaran yang dipilih harus mengutamakan peran siswa dalam pembelajaran dan kerjasama kelompok secara heterogen yang baik tanpa menghilangkan tanggung jawab kepada setiap individu. Metode ini juga dapat menarik perhatian dan meningkatkan keaktifan belajar siswa. Salah satu metode yang tepat digunakan untuk meningkatkan keaktifan dan hasil belajar siswa adalah metode pembelajaran tutor sebaya.

Tutor sebaya adalah seorang atau beberapa orang siswa yang ditunjuk oleh guru untuk membantu guru dalam melakukan bimbingan terhadap kawan sekelas baik dalam kegiatan diskusi kelompok maupun selama proses pembelajaran. Sejalan dengan hal tersebut, Supriyadi (dalam Ahdiyat, 2014:75) mengemukakan bahwa tutor sebaya adalah seorang atau beberapa orang siswa yang ditunjuk dan ditugaskan untuk membantu siswa yang mengalami kesulitan belajar. Tutor tersebut diambil dari kelompok yang prestasinya lebih tinggi. Hal ini didukung dengan pendapat Wihadit (dalam Ahdiyat, 2014:73) tutor sebaya adalah seorang siswa pandai yang membantu siswa lainnya dalam tingkat kelas yang sama. Sisi lain yang menjadikan matematika dianggap siswa pelajaran yang sulit adalah bahasa yang digunakan oleh guru, itulah sebabnya pembelajaran tutor sebaya diterapkan dalam proses pembelajaran matematika.

Pembelajaran dengan metode tutor sebaya merupakan salah satu metode pembelajaran yang dapat memberikan kebebasan kepada siswa yang menjadi tutor untuk mengembangkan metode dalam menjelaskan materi kepada teman-temannya (Rosanti, 2018:3). Siswa diberi tanggung jawab oleh guru agar bisa menjelaskan materi pelajaran pada teman (tutee) yang belum paham sehingga tutor bisa lebih leluasa dalam menyampaikan materi sesuai dengan tujuan pembelajaran. Kondisi pembelajaran yang difasilitasi oleh teman sebaya yang akrab akan membuat tutee mengikuti kegiatan pembelajaran lebih efektif, karena siswa akan lebih leluasa untuk mengatur waktu pembelajaran, tujuan-tujuan belajar, dan target penguasaan materi yang diharapkan. Oleh karena itu, metode tutor sebaya dapat dijadikan alternatif metode pembelajaran oleh guru dalam proses pembelajaran matematika.

Berdasarkan penelitian yang dilakukan oleh Prasojo (2016) tentang peningkatan aktivitas dan hasil belajar matematika dengan metode tutor sebaya pada siswa kelas X IPA 7 diperoleh hasil pengamatan untuk aktivitas siswa ada peningkatan sebesar 15,14\% dan hasil belajar matematika dari kondisi awal ke siklus I meningkat sebesar 14,42\%, sedangkan dari siklus I ke siklus II ada peningkatan sebesar 7,69\%, sehingga secara keseluruhan dari kondisi awal ke siklus II ada peningkatan sebesar 23,22\%. Dengan demikian dapat disimpulkan bahwa dengan penerapan metode tutor sebaya dapat meningkatkan aktivitas dan hasil belajar siswa kelas X IPA 7 SMA 1 Kudus pada materi trigonometri.

Berbeda dengan penelitian diatas, pada penelitian ini peneliti fokus pada penilaian terhadap keaktifan dan hasil belajar siswa dengan bantuan tutor sebaya. Penilaian keaktifan belajar siswa dalam penelitian ini dilihat dari lima indikator yaitu perhatian, kerjasama dan hubungan sosial, mengemukakan gagasan, pemecahan masalah dan disiplin. Sebagai penunjang keaktifan belajar siswa, maka tutor diberi tanggungjawab penuh dalam kegiatan pembelajaran untuk membimbing anggota kelompoknya agar aktif dalam pembelajaran dan diskusi kelompok. Tutor dipilih berdasarkan penilaian harian guru, kemudian tutor dilatih dan dibimbing sebelum kegiatan pembelaran tentang materi yang akan dipelajari. Tutor membantu guru selama proses 
pembelajaran dengan membimbing anggota kelompoknya dalam memahami materi, menyelesaikan soal pada LKK dan menyampaikan hasil diskusi dalam kegiatan presentasi. Dengan demikian, penelitian ini diharapkan berguna bagi siswa agar terlibat aktif dalam pembelajaran, berani bertanya atau menanggapi pertanyaan dari guru, percaya diri dalam menyelesaikan soal yang diberikan dan membantu meningkatkan hasil belajar siswa kelas VIII G SMP Negeri 1 Wagir

\section{METODE PENELITIAN}

Pendekatan yang digunakan dalam penelitian ini adalah pendekatan kualitatif dan Jenis yang penelitian yang digunakan merupakan Penelitian Tindakan Kelas (PTK) dalam upaya meningkatkan hasil belajar siswa. Arikunto (dalam Fatimah, 2017:59) menjelaskan Penelitian Tindakan Kelas (Classroom Action Research) merupakan suatu pencermatan terhadap kegiatan belajar berupa sebuah tindakan yang sengaja dimunculkan dan terjadi dalam sebuah kelas secara bersama dengan tujuan untuk perubahan dan perbaikan yang dilakukan di ruang kelas yaitu kelas VIII SMP negeri 1 Wagir

Penelitian ini bertujuan untuk meningkatkan keaktifan hasil belajar siswa kelas VIII G SMP Negeri 1 Wagir dengan menerapkan metode tutor sebaya. Oleh karena itu, prosedur pengumpulan data yang diperlukan dalam penelitian ini adalah data observasi guru dan tutor, data keaktifan belajar siswa, data hasil tes dan data hasil wawancara.

\section{Observasi}

Pada penelitian ini, observasi terdiri dari 2 bagian yaitu observasi guru dilakukan untuk mengamati keterlaksanaan pembelajaran dengan menggunakan metode tutor sebaya dan observasi tutor dilakukan untuk mengamati aktivitas tutor dalam memimpin diskusi kelompok. Observasi guru diisis oleh guru matematika sedangkan observasi tutor diisi oleh teman sejawat pada lembar observasi yang tersedia..

Data hasil observasi guru dan tutor dihitung menggunakan rumus berikut ini:

$$
\text { Persentase }(\text { ) }=
$$

Dengan kriteria persentase ( ) disajikan pada Tabel 1 berikut ini:

\begin{tabular}{|c|c|c|}
\hline \multicolumn{2}{|c|}{ Tingkat Keberhasilan } & \multirow{2}{*}{$\begin{array}{c}\text { Kategori } \\
\text { Sangat Baik }\end{array}$} \\
\hline & $85 \%$ & \\
\hline $75 \%$ & $85 \%$ & Baik \\
\hline $50 \%$ & $75 \%$ & Cukup \\
\hline $25 \%$ & $50 \%$ & Kurang \\
\hline & $25 \%$ & Sangat Kurang \\
\hline
\end{tabular}

Hasil observasi aktivitas guru dan tutor dikatakan berhasil apabila minimal mencapai kategori baik dengan tingkat keberhasilan 50\% $\quad 75 \%$.

2. Keaktifan Belajar

Indikator keaktifan belajar yang diamati dalam proses pembelajaran disajikan pada Tabel 2 sebagai ini: 
Tabel 2 Indikator Keaktifan Belajar Siswa

\begin{tabular}{|c|c|c|}
\hline No & Indikator & Aspek Penilaian \\
\hline \multirow[t]{3}{*}{1} & \multirow[t]{3}{*}{ Perhatian } & Siswa menjawab salam dan berdoa bersama \\
\hline & & Siswa mendengarkan dan memperhatikan penjelasan guru \\
\hline & & Siswa memperhatikan penjelasan materi dari tutor \\
\hline \multirow[t]{3}{*}{2} & \multirow{3}{*}{$\begin{array}{c}\text { Kerjasama dan } \\
\text { Hubungan Sosial }\end{array}$} & Siswa bekerjasama dengan tutor dalam diskusi kelompok \\
\hline & & Siswa aktif dalam memecahkan masalah dalam kelompok \\
\hline & & Siswa menghargai pendapat teman kelompok \\
\hline \multirow[t]{3}{*}{3} & \multirow{3}{*}{$\begin{array}{c}\text { Mengemukakan } \\
\text { gagasan }\end{array}$} & Siswa berani mengemukakan pendapat kepada tutor \\
\hline & & Siswa merespon pertanyaan atau intruksi dari guru atau tutor \\
\hline & & Siswa berani bertanya pada guru maupun tutor \\
\hline \multirow[t]{3}{*}{4} & \multirow[t]{3}{*}{ Pemecahan Masalah } & $\begin{array}{l}\text { Siswa menyelesaikan masalah yang disajikan pada LKK dengan } \\
\text { baik dan benar }\end{array}$ \\
\hline & & $\begin{array}{l}\text { Siswa bertanya pada guru ketika ada kesulitan dalam } \\
\text { menyelesaikan soal pada LKK }\end{array}$ \\
\hline & & $\begin{array}{l}\text { Siswa bertanya pada tutor apabila ada materi atau soal yang } \\
\text { belum dipahami. }\end{array}$ \\
\hline \multirow[t]{3}{*}{5} & \multirow[t]{3}{*}{ Disiplin } & Siswa menjaga 3ketertiban selama diskusi \\
\hline & & Siswa tertib dalam mempresentasikan hasil diskusi \\
\hline & & Siswa menjaga ketenangan dalam presentasi kelompok \\
\hline
\end{tabular}

Data hasil keaktifan belajar yang diperoleh melalui lembar keaktifan dianalisis dan dinyatakan dalam bentuk persentase yang dihitung dengan menggunakan rumus:

\section{Persentase ()$=$}

Dengan kriteria keberhasilan disajikan pada Tabel 3 berikut ini:

Tabel 3 Kriteria Keaktifan Siswa

\begin{tabular}{cc}
\hline Tingkat Keaktifan & Kategori \\
\hline $85,01 \%-100 \%$ & Sangat Aktif \\
$75,01 \%-85,00 \%$ & Aktif \\
$65,01 \%-75,00 \%$ & Cukup Aktif \\
$55,01 \%-65,00 \%$ & Kurang Aktif \\
$55,00 \%$ & Sangat Kurang Aktif \\
\hline & (Adaptasi Mulyani, 2017:421)
\end{tabular}

Siswa dikatakan aktif apabila lebih dari $75 \%$ siswa mencapai kategori aktif.

3. Tes

Tes dilakukan untuk mengetahui hasil belajar yang dicapai oleh siswa. Nilai siswa secara individu dikatakan tuntas apabila minimal mencapai KKM sebesar 75. Sedangkan dalam menghitung ketuntasan hasil belajar siswa secara klasikal menggunakan rumus berikut:

Keterangan:

(Musworah, 2018:7)

$=$ Persentase ketuntasan

= Jumlah siswa yang tuntas

= Jumlah seluruh siswa 
Hasil belajar siswa dikatakan berhasil apabila minimal 75\% siswa telah mencapai KKM sebesar 75 dan minimal mencapai $75 \%$ tingkat keaktifan.

4. Wawancara

Pada penelitian ini, wawancara dilakukan oleh peneliti terhadap beberapa siswa untuk mengetahui pendapat siswa tentang pelaksanaan pembelajaran dengan menerapkan model pembelajaran tutor sebaya pada materi SPLDV. Subjek wawancara dipilih 3 orang siswa berdasarkan tingkat kemampuan siswa yang diperoleh dari hasil tes. Wawancara dilakukan secara tertulis dengan mengisi lembar wawancara siswa yang telah disediakan.

Tahap-tahap yang dilakukan dalam penelitian ini meliputi tahap pra tindakan dan tahap pelaksanaan:

1. Tahap Pra Tindakan

Melakukan pertemuan awal dengan kepala sekolah untuk meminta izin penelitian dan menemui guru matematika yang mengajar di kelas VIII SMP Negeri 1 Wagir untuk membahas mengenai pembelajaran dengan menerapkan model pembelajaran tutor sebaya pada materi SPLDV.

2. Tahap pelaksanaan Tindakan

a. Merencanakan (plan)

Kegiatan yang dilakukan peneliti adalah:menyusun Rencana Pelaksanaan Pembelajaran (RPP), Lembar Kerja Kelompok (LKK), lembar observasi dan lembar keaktifan siswa, menyiapkan lembar tes dan lembar wawancara bagi siswa, memilih 6 orang siswa sebagai tutor berdasarkan pilihan guru kelas dan memberikan pengarahan dan materi kepada tutor sebelum tindakan dilaksanakan

b. Melaksanakan (act)

Pada tahap ini, peneliti melaksanakan tindakan dengan menerapkan metode tutor sebaya dengan tujuan untuk meningkatkan keaktifan dan hasil belajar siswa dalam pembelajaran matematika khususnya pada pokok bahasan SPLDV. Guru membagi siswa dalam kelompok kooperatif berjumlah 3-4 orang sesuai dengan jumlah tutor yang telah dipilih. Selanjutnya tutor diminta untuk menjelaskan materi kepada teman sebayanya sekaligus sebagai penanggungjawab dalam diskusi kelompok..

c. Mengobservasi (observe)

Pada tahap ini, observasi dilakukan oleh guru matematika dan teman sejawat. Guru matematika bertindak sebagai observer yang menilai aktivitas guru selama proses pembelajaran yakni penilaian terhadap kesesuaian antara pelaksanaan pembelajaran dengan metode tutor sebaya, sedangkan teman sejawat bertindak sebagai observer yang menilai aktivitas siswa berupa keaktifan siswa selama pelaksanaan pembelajaran dengan metode tutor sebaya.

d. Tahap refleksi

Pada tahap ini, peneliti mengemukakan kembali apa yang sudah dilakukan selama pelaksanaan tindakan, kemudian berdiskusi dengan guru matematika dan teman sejawat mengenai pelaksanaan tindakan. Dalam hal ini, guru matematika dan teman sejawat merefleksikan hasil pengamatannya kepada peneliti untuk dijadikan bahan pertimbangan bagi peneliti dalam melaksanakan tindakan selanjutnya.

\section{HASIL DAN PEMBAHASAN}

\section{Hasil Penelitian Siklus I}

Kegiatan pelaksanaan tindakan siklus I secara rinci akan diuraikan dalam setiap tahap sebagai berikut.

\section{a. Tahap Perencanaan}

Tahap perencanaan tindakan siklus I ini, peneliti menyiapkan instrumen penelitian yaitu Rencana Pelaksanaan Pembelajaran (RPP) untuk materi SPLDV, lembar observasi yang digunakan untuk mengamati kegiatan pembelajaran, soal tes yang digunakan untuk postes, dan LKS untuk membantu siswa melaksanakan pembelajaran. Dalam mengamati kegiatan belajar mengajar yang sedang berlangsung, peneliti dibantu oleh 2 orang, 1 orang adalah guru bidang studi matematika kelas VIII G yang akan mengamati kegiatan peneliti dalam melaksanakan 
pembelajaran, dan 1 orang lagi adalah teman sejawat yang akan mengamati aktivitas tutor dan keaktifan siswa selama pembelajaran berlangsung.

b. Tahap Pelaksanaan

Pelaksanaan siklus 1 terdiri dari 2 kali pertemuan . Pertemuan pertama dilaksanakan hari sabtu 30 Maret 2019 pada jam pelajaran 5 - 6 yang berlangsung pada pukul $10.20-11.40$ WIB. Pertemuan kedua dilaksanakan hari senin, 8 april 2019 pada jam pelajaran $3-4$ yang berlangsung pukul 08.40 - 10.00. Materi yang disampaikan pada siklus 1 sesuai dengan indikator-indikator yang terdapat pada kompotensi dasar yaitu memahami bentuk umum SPLDV dan penyelesaian SPLDV dengan metode grafik dan eliminasi

c. Tahap Observasi

Observasi dilakukan terhadap aktivitas guru dalam melaksanakan proses pembelajaran dan aktivitas tutor selama proses diskusi serta keaktifan siswa selama mengikuti pembelajaran menggunakan metode tutor sebaya.

Data hasil observasi guru dan tutor disajikan pada Tabel 4 berikut ini:

Tabel 4 Hasil Observasi Aktivitas Guru dan Tutor Siklus I

\begin{tabular}{lcc}
\hline \multicolumn{1}{c}{ Penilaian } & $\begin{array}{c}\text { Aktivitas } \\
\text { Guru }\end{array}$ & $\begin{array}{c}\text { Aktivitas } \\
\text { Tutor }\end{array}$ \\
\hline Skor maksimal & 64 & 28 \\
Skor perolehan & 47 & 21 \\
Persentase & $73,44 \%$ & $75,00 \%$ \\
Kriteria & Cukup Baik & Cukup Baik \\
Keberhasilan & & \\
\hline
\end{tabular}

Tabel 4 menunjukkan persentase aktivitas guru sebesar 73,44\% dan persentase aktivitas tutor sebesar 75,00 \%, dengan kriteria keberhasilan tindakan masing-masing tergolong cukup baik.

Persentase keaktifan siswa selama pembelajaran pada siklus I dapat dilihat pada Tabel 5 berikut ini:

Tabel 5 Hasil Keaktifan Siswa Siklus I

\begin{tabular}{clc}
\hline No & Indikator & Jumlah Skor \\
\hline $\mathbf{1}$ & Perhatian & 9 \\
2 & Kerjasama dan & 9 \\
3 & Hubungan Sosial & 7 \\
4 & Mengemukakan Gagasan & 10 \\
5 & Demecahan Masalah & 8 \\
\hline Total Skor & $\mathbf{4 3}$ \\
\hline Skor Maksimum & $\mathbf{6 0}$ \\
\hline Persentase Rata-Rata (P) & $\mathbf{7 1 , 6 7 \%}$ \\
\hline
\end{tabular}

Tabel 5 menunjukkan data keaktifan siswa selama pembelajaran diperoleh persentase keaktifan siswa sebesar 71,67\% dengan kriteria keberhasilan tindakan tergolong cukup aktif.

Berdasarkan analisis hasil tes yang telah dilakukan, dapat diketahui bahwa dari 28 siswa terdapat 17 siswa tuntas dalam belajar dengan nilai lebih dari atau sama dengan 75 dan 11 siswa dinyatakan tidak tuntas dalam belajar karena memperoleh nilai di bawah KKM ( ). Dengan demikian dapat dihitung persentase ketuntasan hasil belajar siswa secara klasikal adalah sebesar

. Dari data tersebut dapat diketahui bahwa persentase ketuntasan belajar tersebut masih berada di bawah standar ketuntasan belajar yang ditetapkan yaitu sebesar $75 \%$.

Wawancara dilaksanakan pada akhir siklus I dengan memilih 3 orang sebagai perwakilan siswa dengan kriteria, siswa berkemampuan tinggi, sedang, dan rendah. Siswa yang berkemampuan tinggi saat diwawancarai oleh peneliti tentang model pembelajaran tutor sebaya 
mengemukakan pendapatnya bahwa pembelajaran tersebut membuatnya lebih bersemangat belajar jadi menyenangkan. Kemudian siswa berkemampuan sedang mengungkapkan bahwa pembelajaran tutor sebaya membuatnya mulai berani bertanya kepada teman maupun kepada guru. Terakhir, wawancara dilakukan kepada siswa dengan kemampuan rendah. Siswa tersebut mengemukakan bahwa ia masih ragu-ragu dan malu untuk bertanya pada teman kelompoknya, tetapi senang pembelajaran tutor sebaya.

d. Tahap Refleksi

Berdasarkan hasil refleksi bersama guru matematika dan teman sejawat terhadap hasil observasi dan keaktifan belajar siswa selama pembelajaran diketahui bahwa keaktifan siswa masih belum tampak dalam proses pembelajaran yang berlangsung. Kelompok yang terlihat aktif hanya kelompok I dan IV, sedangkan kelompok yang lain masih belum menunjukkan keaktifan. Dalam kegiatan diskusi baik diskusi kelas maupun diskusi kelompok, kelompok tersebut cenderung pasif terutama dalam menyelesaikan soal yang disajikan pada LKK. Sementara dilihat dari hasil belajar siswa diketahui persentase ketuntasan belajar masih berada di bawah standar ketuntasan belajar yang ditetapkan yaitu sebesar 60,75\%. Dengan demikian, perlu diadakan siklus II sebagai upaya perbaikan terhadap tindakan tersebut.

\section{Hasil Penelitian Siklus II}

a. Tahap Perencanaan

Tahap perencanaan siklus II dimulai dengan menyiapkan rencana pembelajaran untuk subpokok bahasan SPLDV. Peneliti juga telah menyiapkan instrumen penelitian berupa lembar observasi, LKK, soal untuk postes II, dan pedoman wawancara siswa. Alokasi waktu yang diperlukan untuk siklus II ini adalah menit dengan rincian 240 menit digunakan untuk kegiatan pembelajaran, dan 140 menit digunakan untuk pelaksanaan tes siklus II.

b. Tahap Pelaksanaan

Berdasarkan rencana yang sudah dibuat, kegiatan pembelajaran dilaksanakan 2 pertemuan dengan rincian pertemuan pertama dilaksanakan pada hari Rabu 10 April 2019 membahas sub pokok bahasan SPLDV, yaitu memahami bentuk umum SPLDV dan penyelesaian SPLDV dengan metode grafik dan eliminasi, sedangkan pertemuaan kedua dengan alokasi waktu 240 menit dilaksanakan pada hari Sabtu 13 April 2019 membahas sub pokok SPLDV menyelesaikan SPLDV dengan metode subsitusi dan metode gabungan (substitusieliminasi), dilanjutkan dengan tes II yang dilakukan diakhir pembelajaran dengan alokasi waktu 140 menit.

c. Tahap Observasi

Observasi dilakukan terhadap aktivitas guru dalam melaksanakan proses pembelajaran dan aktivitas tutor selama proses diskusi serta keaktifan siswa selama mengikuti pembelajaran menggunakan metode tutor sebaya.

Data hasil observasi guru dan tutor disajikan pada Tabel 4 berikut ini:

Tabel 6 Hasil Observasi Aktivitas Guru dan Tutor Siklus II

\begin{tabular}{lcc}
\hline Penilaian & $\begin{array}{c}\text { Aktivitas } \\
\text { Guru }\end{array}$ & $\begin{array}{c}\text { Aktivitas } \\
\text { Tutor }\end{array}$ \\
\hline Skor maksimal & 64 & 28 \\
Skor perolehan & 54 & 24 \\
Persentase & $84,38 \%$ & $85,71 \%$ \\
Kriteria & Baik & Sangat Baik \\
Keberhasilan & & \\
\hline
\end{tabular}

Tabel 6 menunjukkan persentase aktivitas guru sebesar 84,38\% dengan kriteria keberhasilan tindakan tergolong baik. dan persentase aktivitas tutor sebesar 85,71\%, dengan kriteria keberhasilan tindakan tergolong sangat baik.

Persentase keaktifan siswa selama pembelajaran pada siklus II dapat dilihat pada Tabel 7 berikut ini: 
Tabel 7 Hasil Keaktifan Siswa Siklus II

\begin{tabular}{clc}
\hline No & Indikator & Jumlah Skor \\
\hline $\mathbf{1}$ & Perhatian & 11 \\
2 & Kerjasama dan & 10 \\
3 & Hubungan Sosial & 9 \\
4 & Mengemukakan Gagasan & 11 \\
5 & Pemecahan Masalah & 9 \\
\hline Total Skor & $\mathbf{5 0}$ \\
\hline Skor Maksimum & $\mathbf{6 0}$ \\
\hline Persentase Rata-Rata (P) & $\mathbf{8 3 , 3 3 \%}$ \\
\hline
\end{tabular}

Tabel 7 menunjukkan data keaktifan siswa selama pembelajaran diperoleh persentase keaktifan siswa sebesar 83,33\% dengan kriteria keberhasilan tindakan tergolong aktif.

Berdasarkan analisis hasil tes yang telah dilakukan, dapat diketahui bahwa dari 28 siswa terdapat 22 siswa tuntas dalam belajar dengan nilai lebih dari atau sama dengan 75 dan 6 siswa dinyatakan tidak tuntas dalam belajar karena memperoleh nilai di bawah KKM ( ). Dengan demikian dapat dihitung persentase ketuntasan hasil belajar siswa secara klasikal adalah sebesar 78 . Dari data tersebut dapat diketahui bahwa persentase ketuntasan belajar siswa secara klasikal telah tercapai dan dinyatakan berhasil.

Berdasarkan hasil wawancara yang dilakukan peneliti, dapat disimpulkan bahwa siswa merasa senang dengan pembelajaran tutor sebaya, hanya saja pembelajaran seperti ini kalau terlalu sering dilakukan, siswa akan menjadi bosan. Oleh sebab itu, pembelajaran tutor sebaya hanya dapat menjadi alternatif dalam pembelajaran agar pembelajaran yang dilakukan tidak monoton.

e. Tahap Refleksi

Berdasarkan hasil refleksi bersama guru matematika dan teman sejawat terhadap hasil observasi dan keaktifan belajar siswa selama pembelajaran diketahui bahwa guru telah melaksanakan proses pembelajaran dengan baik dan sesuai dengan rencana yang dibuat. Sementara itu, tutor mampu mengaktifkan anggota kelompok selama diskusi dan siswa aktif dalam kegiatan presentasi hasil diskusi. Dengan demikian dapat dikatakan penerapan tutor sebaya mampu meningkatkan keaktifan dan hasil belajar siswa kelas VIII G SMP Negeri 1 Wagir.

Keaktifan siswa masih belum tampak dalam proses pembelajaran yang berlangsung. Kelompok yang terlihat aktif hanya kelompok I dan IV, sedangkan kelompok yang lain masih belum menunjukkan keaktifan. Dalam kegiatan diskusi baik diskusi kelas maupun diskusi kelompok, kelompok tersebut cenderung pasif terutama dalam menyelesaikan soal yang disajikan pada LKK. Sementara dilihat dari hasil belajar siswa diketahui persentase ketuntasan belajar masih berada di bawah standar ketuntasan belajar yang ditetapkan yaitu sebesar $60,75 \%$. Dengan demikian, perlu diadakan siklus II sebagai upaya perbaikan terhadap tindakan tersebut.

\section{Pembahasan}

Berdasarkan pemaparan data hasil observasi keaktifan belajar siswa di atas dapat disimpulkan bahwa penerapan metode pembelajaran tutor sebaya dapat meningkatkan keaktifan belajar siswa. Hal ini diperkuat dengan penelitian yang telah dilakukan Idris (2017) bahwa dengan menerapkan metode pembelajaran tutor sebaya dapat meningkatkan keaktifan belajar siswa. Pembelajaran dengan tutor sebaya mempengaruhi pola interaksi siswa. Pembelajaran tersebut dapat menambah kepercayaan diri siswa dalam mengemukakan pendapatnya kepada orang lain. Sejalan dengan hal tersebut, Maryani (dalam Sidiq, 2018:44) menjelaskan metode tutor sebaya juga dapat menumbuhkan tanggung jawab siswa terhadap pembelajarannya sendiri dan membuat siswa menjadi lebih aktif 
Berdasarkan pemaparan data peningkatan hasil belajar siswa, maka dapat disimpulkan bahwa penerapan metode pembelajaran tutor sebaya dapat meningkatkan hasil belajar siswa. Adanya peningkatan hasil belajar siswa terjadi karena beberapa faktor, salah satunya ialah kemampuan tutor dalam bekerjasama dan mampu mengarahkan anggota kelompok selama pembelajaran. Friani (2016) dalam penelitiannya menjelaskan bahwa penerapan model pembelajaran tutor sebaya, siswa lebih diberikan kesempatan untuk terlibat secara aktif yaitu terjadi interaksi dan transfer pengetahuan dari tutor ke anggota kelompok. Tutor membantu temannya untuk dapat memahami konsep materi yang sedang dipelajari.

Peningkatan hasil belajar dengan menerapkan metode pembelajaran tutor sebaya pada penelitian ini didukung oleh penelitian yang relevan yang telah dilakukan oleh Ahdiyat (2014) bahwa penggunaan metode tutor sebaya dalam proses pembelajaran bisa menjadi pilihan dalam mengajarkan matematika di sekolah, karena berpengaruh terhadap hasil belajar matematika siswa Metode tutor sebaya memberikan motivasi siswa untuk belajar kognitif, afektif, dan psikomotorik, sehingga hasil belajar siswa meningkat secara optimal. Penelitian lain dilakukan oleh Palistini (2018) menunjukan bahwa penerapan metode tutor sebaya dalam pembelajaran dapat meningkatkan hasil belajar siswa. Hal ini tebukti rata-rata hasil belajar, daya serap siswa, dan ketuntasan klasikal siswa pada siklus I sampai siklus II meningkat.

\section{PENUTUP}

Berdasarkan hasil penelitian dan pembahasan penelitian tindakan kelas yang dilaksanakan di kelas VIII G SMP Negeri 1 Wagir pada materi Sistem Persamaan Linear Dua Variabel (SPLDV) diperoleh kesimpulan sebagai berikut: (1) penerapan metode pembelajaran tutor sebaya dapat meningkatkan keaktifan belajar siswa, (2) penerapan metode pembelajaran tutor sebaya dapat meningkatkan hasil belajar siswa.

Saran bagi guru agar dapat mempertimbangkan untuk menggunakan metode tutor sebaya dalam pembelajaran agar suasana pembelajaran menyenangkan dan bervariasi. Namun demikian perlu diperhatikan bahwa penggunaan metode ini tidak diterapkan secara terus menerus karena akan membuat siswa bosan dan jenuh. Sedangkan saran bagi peneliti selanjutnya diharapkan dapat melakukan penelitian dengan menerapkan metode pembelajaran tutor sebaya pada materi yang berbeda sehingga dapat membantu meningkatkan keaktifan dan hasil belajar siswa.

\section{DAFTAR PUSTAKA}

Ahdiyat, Maman. 2014. Metode Tutor Sebaya untuk Meningkatkan Hasil Belajar Matematika pada Materi Pengolahan Data. Jurnal Formatif, 4(1): 71-79,

Fatimah, S. 2017. Upaya Meningkatkan Hasil Belajar Matematika Materi Statistik melalui Model Group Investigation Berbasis Kontekstual pada Siswa Kelas XI IPA 2 Semester I SMA 15 Semarang Tahun Ajaran 2014/2015. Laporan Penelitian Tindakan Kelas (PTK), 4 (1),

Friani, S.A. 2016. Penerapan Model Pembelajaran Tutor Sebaya (Peer Tutoring) untuk Meningkatkan Hasil Belajar Kimia Siswa di Kelas XI IPA SMA Srijaya Negara Palembang. Jurnal Penelitian Pendidikan Kimia, 3 (1),

Idris, R. P. 2017. Penerapan Pembelajaran Model Tutor Sebaya (Peer Tutoring) untuk Meningkatkan Keaktifan dan Prestasi Belajar Siswa dalam Mata Pelajaran Mekanika Teknik Kelas X Tm-B SMK N 5 Surakarta 2016/2017. Seminar Nasional Pendidikan Vokasi Ke 2

Mulyani, S. 2017. Penerapan Model Kooperatif Tipe Team Accelerated Intruction (TAI) untuk Meningkatkan Keaktifan dan Hasil Belajar Peserta Didik pada Pembelajaran Tematik. Jurnal Pendidikan Guru Sekolah Dasar. 2(2),

Muswaroh, S. 2018. Penerapan Model Pembelajaran Kooperatif Tipe Think Pair Share Berbantuan Media Puzzle untuk Meningkatkan Keaktifan dan Hasil Belajar Siswa pada Mata Pelajaran IPS Kelas V Sdn Soge Kandanghaur Indramayu. Jurnal Kajian Pendidikan dan Hasil Penelitian, 4 (2), 
Nurmala. 2016. Penerapan Model Pembelajaran Tutor Sebaya untuk Meningkatkan Hasil Belajar Siswa Kelas V SDN 20 Toli-Toli pada Operasi Hitung Campuran Bilangan Bulat. Jurnal Kreatif Tadulako, 4 (9),

Palistini, L.A. 2018. Penerapan Metode Tutor Sebaya untuk Meningkatkan Hasil Belajar Pendidikan Agama Hindu pada Siswa Kelas III Sekolah Dasar Negeri 1 Sukadana. Jurnal Penjaminan Mutu Institut Hindu Dharma Negeri Denpasar, 4(1),

Prasojo, T. 2016. Peningkatan Aktivitas dan Hasil Belajar Matematika dengan Metode Tutor Sebaya pada Siswa Kelas X IPA 7 Materi Trigonometri SMA Negeri 1 Kudus. Jurnal Matematika Kreatif-Inovatif, (Online), 7 (1) : 31-40

Rosanti, D. 2018. Penerapan Metode Pembelajaran Tutor Sebaya untuk Meningkatkan Aktivitas dan Hasil Belajar Siswa di SMA Negeri 9 Pontianak. Jurnal Pendidikan Matematika dan IPA, 9 (2): 1-11,

Sholihah, D. A. 2015. Keefektifan Experiential Learning Pembelajaran Matematika MTs Materi Bangun Ruang Sisi Datar. Jurnal Riset Pendidikan Matematika, (Online), 2 (2): 175-185,

Sidiq, H.A. 2018. Penerapan Metode Tutor Sebaya Terhadap Hasil Belajar Siswa pada Kompetensi Dasar Memasang Sistem Penerangan dan Wiring Kelistrikan di SMK. Journal Of Mechanical Engineering Education, 5 (1),

Wibowo, N. 2016. Upaya Peningkatan Keaktifan Siswa Melalui Pembelajaran Berdasarkan Gaya Belajar di SMK Negeri 1 Saptosari. Jurnal Electronics, Informatics, and Vocational Education, 1 (2),

Zayyin, A. N. 2017. Meningkatkan Keaktifan dan Hasil Belajar Matematika dengan Model Pembelajaran Kooperatif Tipe Group Investigation. Jurnal Pendidikan Matematik, 5 (1). 